\title{
Fishing resources in the rio Cuiabá basin, Pantanal do Mato Grosso, Brazil
}

\author{
Lúcia. A. F. Mateus*, Jerry M. F. Penha** and Miguel Petrere***
}

The rio Cuiabá is one of the most important tributaries of the upper rio Paraguay basin that form the Pantanal wetlands. The fishing resources of the rio Cuiabá basin were studied based on landing data obtained from the Fish Market of the city of Cuiabá, State of Mato grosso, Brazil. A description is given of the composition and origin of the 2000 and 2001 catch. The rio Cuiabá is the main source of fish for Cuiabá, although some fish sold locally comes from the rio Paraguay. The 2000-2001 catch consisted mainly of migratory species. The main landed species were the pimelodids pintado - Pseudoplatystoma corruscans, cachara - Pseudoplatystoma fasciatum, and jaú - Paulicea luetkeni, and the characiforms pacu - Piaractus mesopotamicus, piraputanga - Brycon microlepis, piavuçu - Leporinus macrocephalus, and dourado - Salminus brasiliensis. Large catfishes (Pimelodidae) represented $70 \%$ of the landed fish, among which pintado was the most abundant. The data indicate that current catches are smaller than those recorded in the early 1980s and fish are caught far off the urban zone. Moreover, although the number and composition of species caught were similar to those of the 80s, the distribution of species abundance has changed. Currently, fisheries catch more carnivorous species than fish from lower trophic levels. These findings cannot be credited solely to overfishing, but appear to result from a complex interaction of factors, i.e., environmental degradation, changes in market preferences, and restrictive legal fishing regulations.

O recurso pesqueiro da bacia do rio Cuiabá, um dos mais importantes tributários da bacia do Alto Paraguai, formadora do Pantanal, foi estudado a partir dos dados de desembarque de pescado obtidos no Mercado do Porto de Cuiabá, Mato Grosso, Brasil. São descritas a composição e procedência das capturas para os anos de 2000 e 2001 . O rio Cuiabá é a fonte dominante de pescado para a cidade de Cuiabá, mas uma parte do pescado comercializado localmente é oriunda do rio Paraguai. Além disso, atualmente o pescado vem de regiões mais distantes da zona urbana. Constatou-se que a pesca incide basicamente sobre espécies migradoras. As principais espécies capturadas foram os pimelodídeos pintado - Pseudoplatystoma corruscans, cachara - Pseudoplatystoma fasciatum e jaú - Paulicea luetkeni e os caraciformes pacu - Piaractus mesopotamicus, piraputanga - Brycon microlepis, piavuçu - Leporinus macrocephalus e dourado - Salminus brasiliensis. Os grandes bagres (Pimelodidae) foram os responsáveis por $70 \%$ do pescado desembarcado no período de estudo, dentre os quais o pintado foi a espécie mais capturada. Os dados indicam que as capturas atuais estão bem aquém daquelas registradas no início da década de 80 . Além disso, apesar do número e composição de espécies capturadas serem similares àqueles da década de 80 , a distribuição da abundância mudou. Atualmente a pesca captura mais espécies carnívoras do que espécies de níveis tróficos inferiores. Estes achados não podem ser creditados somente a sobrepesca, mas parecem resultar de uma complexa interação entre degradação ambiental, mudanças na preferência de mercado e medidas legais restritivas à pesca.

Key words: fishery management, aquatic resource, freshwater fisheries.

\section{Introduction}

In tropical regions, freshwater aquatic resources are important sources of protein. In Amazon, for instance, the riverine population consumes more fish than the world's average (Barthem et al., 1997). Fishing in this region is the most important traditional extractive activity (Petrere, 1992). De- spite its importance, tropical fishing is still often poorly managed. Fishing scientists alone cannot solve this situation, which is of a political and socioeconomic nature, although they may provide the biological understanding required to rehabilitate poorly managed stocks (Gayanilo \& Pauly, 1997). Knowledge of what species are caught and in what quantities, and of how exploited populations react to different de-

\footnotetext{
*Departamento de Produção Animal, FAMEV/UFMT. 78060-900 Cuiabá, MT, Brazil. e-mail: 1mateus@terra.com.br **Departamento de Botânica e Ecologia, IB/UFMT. 78060-900 Cuiabá, MT, Brazil. e-mail: jerrym@terra.com.br ***Departamento de Ecologia, IB/UNESP. 13506-900 Rio Claro, SP, Brazil. e-mail: mpetrere@ @rc.unesp.br
} 
grees of fishing effort, is essential for sound management of any stock.

Fishing is an ancient activity in Pantanal. Until the 1960's, it was characterized simply as a subsistence activity, chiefly due to the lack of conditions for fish storage that made the establishment of a profitable activity difficult. It was only from the 60's and 70's, with the installation of ice plants in the region, that fishing became commercially important (Costa Jr., 1993; Medeiros, 1999).

Aguirre (1945), Paiva (1983), Ferraz de Lima (1981a; 1981b; 1987; 1986/87; 1993), Ferraz de Lima \& Chabalin (1984) and Silva (1986) discussed a variety of historical, economic and social aspects of fishing and of fishing production in Pantanal. Fish landed from professional fishing recorded in the upper rio Paraguay basin from 1980 to 1989 (except 1985) varied from 3,441 to 10,022 tons, with Mato Grosso showing an average of 4,862 tons and Mato Grosso do Sul 2,206 tons (PCBAP, 1995). However, due to clandestine fishing and the absence of a statistical fishing data collection system in the state of Mato Grosso (MT), the real quantity and quality of fish nowadays landed is unknown. In Mato Grosso do Sul (MS), where a statistical fishing data collection system is in place, the total landing of fish from 1994 to 1999 averaged 1,415 tons/year, 24\% landed by professional fishers and $76 \%$ by sports fishers (Catella, 2001). Fish are caught chiefly in the main channel of rivers, while lakes are used for catching bait or for normal fishing during floods. Fishing with gillnets today are forbidden by state law in both MT and MS. The only method generally allowed is hook-and-line. Even so, a variation of this technique is widely used: the branch hook, gear whereby the fishing line, with hook, lead and bait tied to a tree branch or rod at the river's edge (Costa Jr., 1993; Da Silva \& Silva, 1995; PCBAP, 1995; Medeiros, 1999; Medeiros et al., 2002; Petrere et al., 2002).

Unfortunately, since MT has no statistical fishing data collection system, the information available for management is partial and punctual. However, the city of Cuiabá has a municipal market that concentrates a large part of the region's fish trade, thus allowing for estimates of the fishing production in the rio Cuiabá basin based on the fish landed there. Therefore, the purpose of this work was to characterize the fishing production in the rio Cuiabá basin in terms of total and monthly landing by species and origin, based on the fish landed in the Fish Market of Cuiabá, MT and to compare the current landing with that of the 1980's.

Study Area. The Pantanal is a floodplain of approximately $140,000 \mathrm{~km}^{2}$, which is subject to alternating dry and wet seasons. It is part of the basin of the upper rio Paraguay, which springs from the Serra dos Parecis (northern MT) and flows sinuously southward to Corumbá (MS).

The rio Paraguay receives inflowing waters from innumerable slow flowing tributaries containing a lot of sediments that, through flooding, are deposited on the floodplain (Carvalho, 1986). The river's main tributaries in Brazilian terri- tory are, on its right margin, rio Jauru, rio Cabaçal and rio Sepotuba, and on its left margin, rio Cuiabá, rio Taquari, rio Miranda and rio Apa.

The rio Cuiaba is one of the main tributaries of the rio Paraguay. Its drainage basin is situated between $14^{\circ} 18^{\prime}$ and $17^{\circ} 00^{\prime} \mathrm{S}$, and $54^{\circ} 40^{\prime}$ and $56^{\circ} 55^{\prime} \mathrm{W}$, and covers approximately $28,732 \mathrm{~km} 2$ (FEMA, 1995). The main urban zone of the basin is the city of Cuiabá, which, together with neighboring Várzea Grande, has a population of about 700,000.

The hydrological cycle can be divided into four periods following the water level of the river (Da Silva, 1990) (Fig. 1): (i) full - January, February and March - the rainy season, when the rivers overflow and invade floodable areas; (ii) ebb - April, May and June - the period of ebbing waters, i.e., when the waters recede to the river beds; (iii) dry - July, August and September - the period with little rainfall, when the rivers flow practically only in their beds; and (iv) flood - October, November and December - beginning of the rain, when the river levels begin to rise.

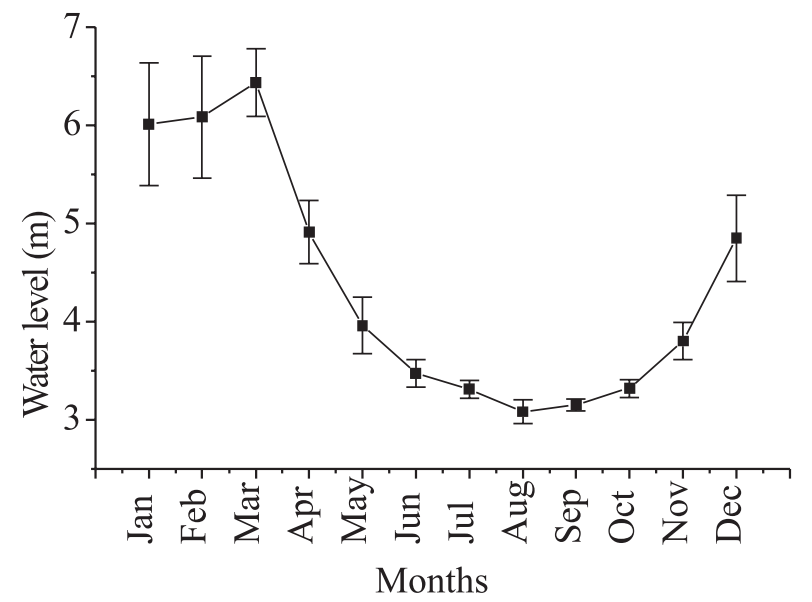

Fig. 1. Monthly mean variation of the rio Cuiabá water level obtained at the City of Santo Antônio do Leverger. Mean estimated from 1993 to 2001. Bars indicate \pm 1 standard error.

\section{Material and Methods}

Monthly and annual data on the catch, by species and total, were obtained from the records of the Forestry Police that, since February 2000, have been recording the total weight of each landing in the Cuiabá Fish Market. Fish were separated according to their origin: commercial fishing (caught by hook-and-line) or produced in captivity. Weight per species (the most important ones) and their origin have been recorded since mid-July 2000. The data from August to October 2000 and from March to October 2001 are summarized here and analyzed monthly by species and origin.

Based on the information regarding the origin, locations were divided, with the help of maps, into regions according to the drainage (Paraguay or Cuiabá), their proximity to each other, and the main towns containing fisher- 
men colonies. The purpose of this subdivision was to detect some spatial pattern in the tendency for catching the various exploited species.

The rio Cuiabá, from where most of the catch sold in the Cuiabá Fish Market comes, was divided into 5 regions (1 to 5) while the rio Paraguay was divided into 2 regions (6 and 7), as follows:

\section{Rio Cuiabá:}

Region 1 - located upstream of the city of Cuiabá, encompassing the sites belonging to the colonies of Nobres and Rosário Oeste.

Region 2 - comprising the localities close to Cuiabá and Várzea Grande.

Region 3 - encompasses the region of Santo Antônio do Leverger and its fishing communities.

Region 4 - comprises the region of Barão de Melgaço.

Region 5 - includes the sites of Porto Cercado and Porto Jofre, close to the confluence with the rio Paraguay.

\section{Rio Paraguay:}

Region 6 - close to the town of Barra do Bugres.

Region 7 - comprises the region of Cáceres.

In order to detect temporal changes in the catches from the rio Cuiabá, its current characteristics were compared with those of the 80 's. The data from the 80 's were taken from Ferraz de Lima (1981a; 1981b; 1987; 1986/87; 1993) and Ferraz de Lima \& Chabalin (1984). The evaluation was based on three criteria: total quantity of the catch and its monthly variation, number and ranking of species caught. The catches of pintado and cachara were pooled as surubim for purposes of comparison with the 80's. A comparison of the ranking of the jaú, dourado, pacu, curimbatá, and surubim was possible.

\section{Results}

\section{Quantitative description of the fish landed in the Cuiabá} Fish Market.

Total commercial landings in 2000 and 2001 were 232 tons and 162 tons, respectively. Monthly average landing in 2000 was $18,030 \mathrm{~kg}$, with a coefficient of variation (CV) of $64.3 \%$. February was the month with the lowest landing while March was the highest. The high $\mathrm{CV}$ was due to the substantial difference in the landing of February and July in relation to the other months. In 2001, the average monthly landing was $20,096 \mathrm{~kg}$, with a CV of $7.13 \%$; June and May were the months with lowest and highest landing, respectively. Fishing was forbidden during November and December of 2000 and January and February of 2001 due to the reproductive period. Landed fish were caught mainly in the basin of the upper rio Paraguay, and main species were the pintado (Pseudoplatystoma corruscans - 33.5\%), jaú (Paulicea luetkeni - 16.6\%), cachara (Pseudoplatystoma fasciatum $14 \%$ ), pacu (Piaractus mesopotamicus - 10.4\%), piraputanga (Brycon microlepis - 6.6\%), barbado (Pinirampus pirinampu - 4.2\%), dourado (Salminus brasiliensis - $3.1 \%$ ), piavuçu (Leporinus macrocephalus $2.9 \%$ ), as well as others such as the jurupensém (Sorubim cf. lima), jurupoca (Hemisorubim platyrhynchos), and curimbatá (Prochilodus lineatus). Other species of less commercial value, but which are quite important in subsistence fishing and sometimes commercialized, are the traíra (Hoplias malabaricus), piranha (Pygocentrus nattereri, Serrasalmus spilopleura and S. marginatus), pacupeva (mainly Mylossoma spp.), piava (Schizodon borellii) and mandi (Pimelodus maculatus). A minor portion of the fish came from the rio Teles Pires in MT (manly mantrinchãs Brycon spp.), which is part of the Amazon River basin. There were also occasional landings of fish (mostly surubim catfish Pseudoplatystoma spp.) from the state of Pará and rarely from Argentina.

Unfortunately, up to July 2000 there was no record of which river the fish came from (Table 1). However, it is clear that a large part of the fish landed at Cuiabá Fish Market came from the rio Cuiabá basin, in both 2000 and 2001, as expected in view of its location.

Captivity fish also participated in the fish trade at Cuiabá Fish Market, and the amount landed in 2001 was about twice as much as that of 2000, evidencing a tendency for growth in this sector, especially in April (Table 1).

In terms of percent participation, the rio Cuiabá accounted for over half of the total fish landed, including that from captivity. Of this total, $87 \%$ of the landing of 2000 and $77 \%$ of 2001 came from the catch in this river.

Table 1. Total fish landed (kg) in the Cuiabá Fish Market in 2000 and 2001 per month, river and year from commercial fishing and captivity.

\begin{tabular}{|c|c|c|c|c|c|c|c|c|c|c|c|c|}
\hline \multicolumn{7}{|c|}{2000} & \multicolumn{6}{|c|}{2001} \\
\hline Month & $\begin{array}{c}\text { Rio } \\
\text { Cuiabá }\end{array}$ & $\begin{array}{c}\text { Rio } \\
\text { Paraguay }\end{array}$ & $\begin{array}{l}\text { Rio Teles } \\
\text { Pires }\end{array}$ & Other & Total & Captivity & $\begin{array}{c}\text { Rio } \\
\text { Cuiabá }\end{array}$ & $\begin{array}{c}\text { Rio } \\
\text { Paraguay }\end{array}$ & $\begin{array}{l}\text { Rio Teles } \\
\text { Pires }\end{array}$ & Other & Total & Captivity \\
\hline Feb & & & & & 9831 & 2892.5 & 0 & 0 & 0 & 0 & 0 & \\
\hline Mar & & & & & 34844 & 526 & 17007 & 2075 & 65 & 0 & 19147 & 6934.5 \\
\hline Apr & & & & & 32337 & 1547 & 13668 & 2917 & 0 & 0 & 16585 & 26598.5 \\
\hline May & & & & & 32772 & 2580 & 19037 & 4083 & 706 & 0 & 23827 & 2446 \\
\hline Jun & & & & & 28348 & 3949 & 11669 & 2076 & 750 & 0 & 14495 & 3830 \\
\hline Jul & & & & & 14024 & 6529 & 12582 & 5292 & 1448 & 0 & 19323 & 2015 \\
\hline Aug & 18565 & 6115 & 175 & 1200 & 26055 & 3348 & 14916 & 6054 & 2134 & 0 & 23105 & 3832 \\
\hline Sep & 18797 & 7604 & 976 & 402 & 27879 & 2306 & 15837 & 6709 & 729 & 0 & 23276 & 3971 \\
\hline Oct & 17660 & 7022 & 336 & 1210 & 26228 & 3677 & 10891 & 10218 & 1018 & 0 & 22128 & 6007 \\
\hline Total & 60552 & 22613 & 1763 & 2812 & 232320 & 23825.5 & 115607 & 39424 & 6850 & 0 & 161886 & 55634 \\
\hline
\end{tabular}


Table 2. Total landing (kg) per month and species from the rio Cuiabá in 2000 and 2001.

\begin{tabular}{|c|c|c|c|c|c|c|c|c|c|c|c|}
\hline \multicolumn{4}{|c|}{2000} & \multicolumn{8}{|c|}{2001} \\
\hline & Aug & Sep & Oct & Mar & Apr & May & Jun & Jul & Aug & Sep & Oct \\
\hline Pintado & 4169 & 6555 & 5527 & 9179 & 3873 & 9474 & 4430 & 3227 & 4399 & 5753 & 3692 \\
\hline Jaú & 3842 & 3960 & 2223 & 3291 & 3234 & 3023 & 2053 & 2702 & 4123 & 3689 & 1884 \\
\hline Cachara & 2414 & 2316 & 3925 & 3157 & 2038 & 1669 & 1334 & 894 & 478 & 987 & 1181 \\
\hline Pacu & 1090 & 994 & 2066 & 621 & 2179 & 1237 & 691 & 775 & 1358 & 1444 & 1066 \\
\hline Piraputanga & 2998 & 1050 & 744 & 70 & 379 & 1769 & 1264 & 1646 & 1431 & 1248 & 488 \\
\hline Piavuçu & 1679 & 1061 & 560 & 0 & 9 & 346 & 242 & 1028 & 801 & 688 & 80 \\
\hline Barbado & 809 & 284 & 995 & 300 & 249 & 566 & 227 & 543 & 877 & 561 & 1146 \\
\hline Dourado & 488 & 600 & 416 & 131 & 366 & 619 & 813 & 938 & 684 & 699 & 406 \\
\hline Other & 1075 & 1676 & 2016 & 256 & 1339 & 333 & 612 & 827 & 764 & 766 & 946 \\
\hline Total & 18564 & 18496 & 18472 & 17005 & 13666 & 19036 & 11666 & 12580 & 14915 & 15835 & 10889 \\
\hline
\end{tabular}
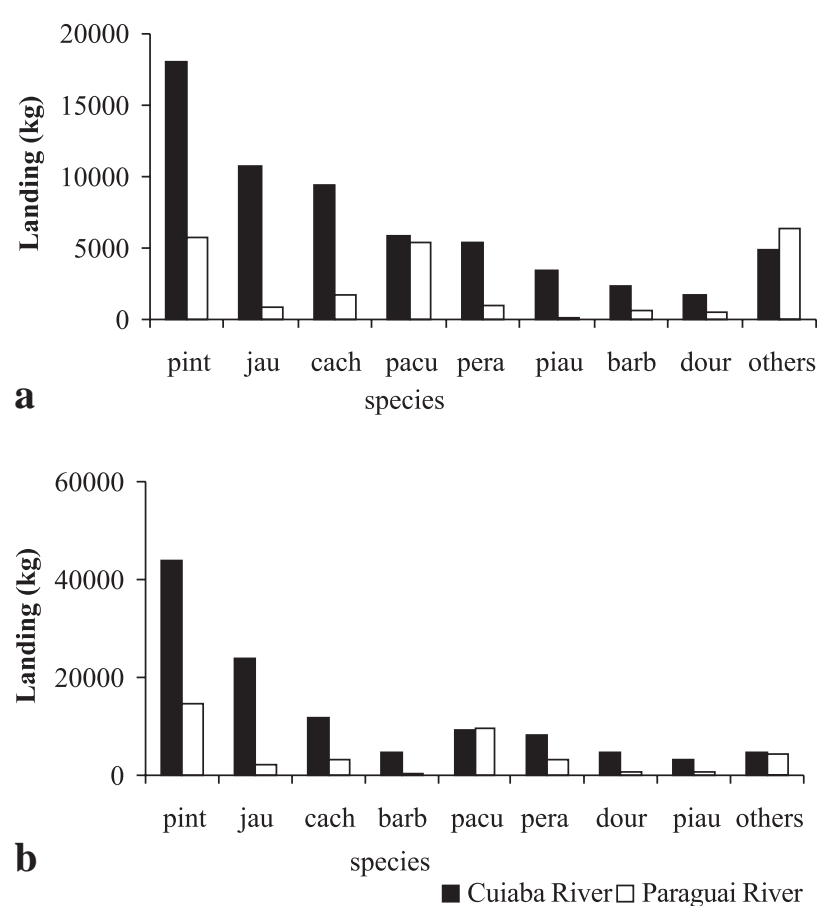

Fig. 2. Landing by species and by river from July to October 2000 (a), and from March to October 2001 (b) at the Cuiabá market $($ pint $=$ pintado; cach $=$ cachara barb = barbado; pera $=$ piraputanga; dour $=$ dourado $)$.

Starting in July 2000, when records of landings by species began to be reported, up to October 2001 (except for the months when fishing was forbidden, i.e., November 2000 to February 2001), 241 tons of fish came from the rio Paraguay (62 tons) and rio Cuiabá (179 tons). Of this total, the most important fish were pintado (34.2\%), jaú (15.6\%), pacu $(12.6 \%)$, cachara $(11 \%)$, piraputanga $(7.4 \%)$, barbado $(3.2 \%)$, dourado $(3.2 \%)$, and the piavuçu $(3.2 \%)$, the remaining species together corresponded to $9.7 \%$.

Landing pattern for all species was the same in 2000 and 2001, i.e., the largest amount came from the rio Cuiabá, with the exception of pacu, that, in 2001, presented higher landing in the rio Paraguay (Fig. 2). This fact should be viewed with caution, because the 2000 data do not correspond to a complete year of fishing. A comparison of the landing data by species from these two rivers indicated that $75.3 \%$ of the pintado, $92.1 \%$ of the jaú, $50.4 \%$ of the pacu, $80.6 \%$ of the cachara, $77 \%$ of piraputanga, $87.1 \%$ of the barbado, $82.4 \%$ of the dourado, and $86.7 \%$ of the piavuçu originated from the rio Cuiabá and the remainder of each of these species came from the rio Paraguay.

The largest landings were recorded in the months of May, for the rio Cuiabá (16.5\% of their annual total), and in October, for the rio Paraguay (26\% of their annual total). The smallest landings per river occurred in October, for the Cuiabá, and in March, for the rio Paraguay (Table 1).

\section{Quantitative description of the fish landed from the rio Cuiabá.}

The catch from the rio Cuiabá corresponded to $71.2 \%$ of the total landed at the Cuiabá fish market in 2001. The monthly variation of this landing per species is shown in Table 2, which indicates that, between August 2000 and October 2001, the amount of fish landed varied from 10,891 $\mathrm{kg}$ in October 2001 to $19,036 \mathrm{~kg}$ in May 2001. The monthly average landing was $14,728 \mathrm{~kg}$, with a CV of $36.8 \%$. July 2000 was excluded from the analyses because the survey covered only the second half of the month.

Pimelodids represented $70 \%$ of the total landing from the rio Cuiabá, with three species of this family ranking first place in the catches. The characiforms corresponded to $25 \%$ of the total catch from the rio Cuiabá. The species ranking first place in the landing was the pintado (34\%), followed by the jaú (20\%), cachara (12\%), pacu (9\%), piraputanga (8\%), barbado, dourado and piavuçu (4\% each), and others $(5 \%)$.

Variation in landing per species during each month of 2000 and 2001 was observed (Table 2). The pintado showed two great landing peaks, one in March and the other in May 2001. The amount of jaú landed remained relatively constant throughout the period, with a slight increase in August 2001. The largest landing of cachara occurred in October 2000, while in August 2001 its landing was considerably lower than in other months. The barbado, despite the low amount landed, showed a peak of over a ton in October 2001.

Pacu was the most important characiform, with the greatest landings registered in October 2000 and April 2001. Piraputanga showed relatively constant landing from May to September, but was considerably lower in the other 
months. The landing of piavuçu suggests a greater catch between July and September, with negligible amounts in the other months. The dourado appeared in greater quantities in June and July, dropping to lower amounts in the remaining months.

Among the regions of the rio Cuiabá, region 5 (Porto Cercado and Porto Jofre, downstream from Barão de Melgaço) was the one that most contributed to the landing at the Cuiabá Fish Market (33\%). Region 2 (4\%) was the one with the smallest contribution, even though it is the closest location to the city of Cuiabá. Region 1 contributed with $26 \%$, region 3 with $23 \%$, and region 4 with $14 \%$ of the landings. Region 5 was also the most important in terms of catch in almost every month except for October, when the greatest amount of fish originated from Region 3 (Fig. 3).
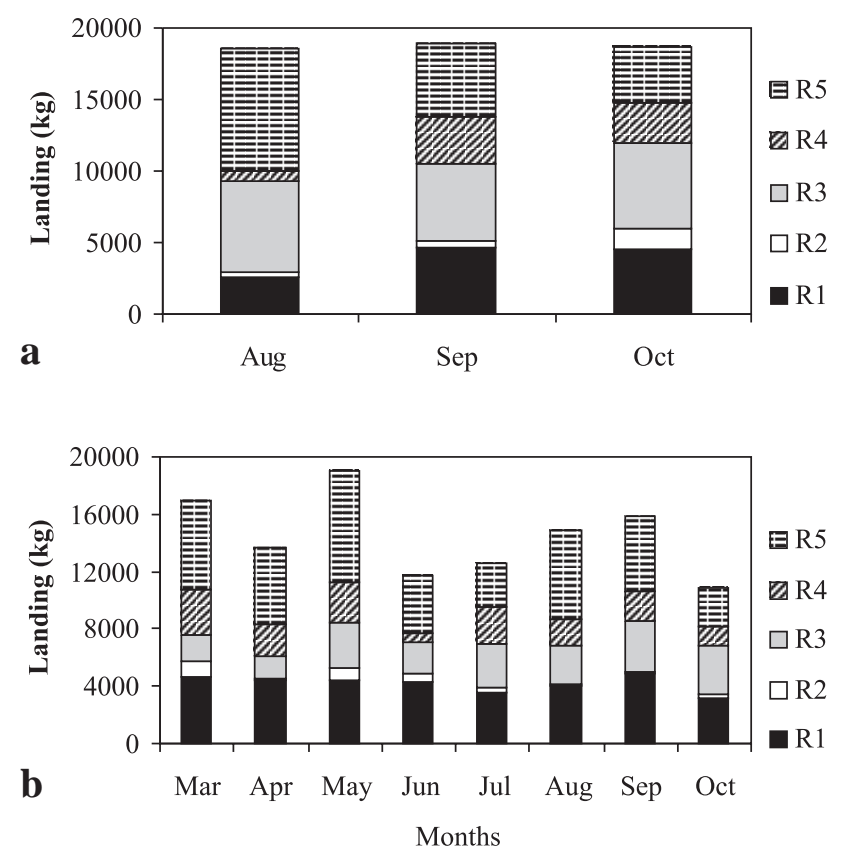

Fig. 3. Monthly landing of catch by region $(\mathrm{R} 1=$ region $1 ; \mathrm{R} 2$ $=$ region $2 ; \mathrm{R} 3=$ region $3 ; \mathrm{R} 4=$ region $4 ; \mathrm{R} 5=$ region 5 ) of the rio Cuiabá in 2000 (a) and 2001 (b).

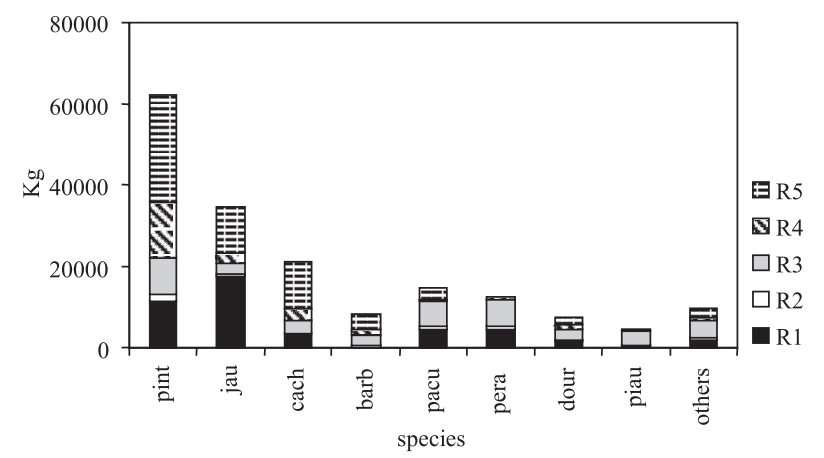

Fig. 4. Total landing of catch in kilograms by region $(\mathrm{R} 1=$ region $1 ; \mathrm{R} 2=$ region $2 ; \mathrm{R} 3=$ region $3 ; \mathrm{R} 4=$ region $4 ; \mathrm{R} 5=$ region 5) of the rio Cuiabá for each species (pint = pintado; cach $=$ cachara $;$ barb $=$ barbado; pera $=$ piraputanga ; dour $=$ dourado).
The importance of the regions of origin of the landed species varies. The jaú came mainly from region 1 . The greatest landings of pintado, cachara and barbado came from region 5, a region that is little representative of characiforms. On the other hand, most of the pacu, piraputanga, dourado and piavuçu came from region 3 , where only a minor catch of pimelodids was landed. Although it ranked fourth in total landings (14\%), region 4 stood out for its amount of catfish, but showed a negligible catch of characiforms (Fig. 4).

Although the landings by species were not uniformly distributed along the months, it is clear that, in general, the region of greatest importance in total landing for a given species follows the same monthly pattern. The case of the jaú stands out, that came mainly from region 1 . However, in August and September 2001, the most important region in terms of landing was region 5, which also holds true for August 2000 (Figs. 5 and 6).

\section{Comparison between current landing with that of the 1980's.}

The data indicate that the annual catch falls far short of that recorded in the early 80's (Fig. 7). The monthly variation in current catches is less marked than in the 1980's (Fig. 8), mainly because the months of June and July in that decade showed a very high peak in relation to the other months.

Obviously, since the total annual landing today is lower than during the 80 's, the landing per species is lower as well. Hence, one finds that there was a substantial reduction in the landing of surubim, dourado and pacu - the most important species, and a drastic reduction in the catch of curimbatá, which today appears in the category of other species. A comparison of today data with that of the 80's indicates that the catches of jaú remained relatively stable (Fig. 9).

Although the number and composition of species presently caught were similar to that of the 80's, the distribution of abundances in the landing data (species ranking) changed. According to Ferraz de Lima \& Chabalin (1984), between 1980 and 1983, surubim and pacu held about the same importance (about 25\%), with curimbatá representing about $15 \%$ of the total. Today, more than $50 \%$ of the catch landed is represented by surubim, with jaú ranking second (20\%) and pacu third, representing less than $10 \%$ of the total catch landed, in weight. The remaining species together represent around $20 \%$ of the entire catch landed and originating from the rio Cuiabá.

\section{Discussion}

The rio Cuiabá is the predominant source of fish for the city of Cuiabá. However, part of the fish commercialized locally comes from the rio Paraguay, in the regions of Cáceres and Barra do Bugres. This fact was not recorded in the fishing statistics of the 80's. Moreover, nowadays the fish comes from regions further away from the urban zone, involving practically the entire extent of the rio Cuiabá 

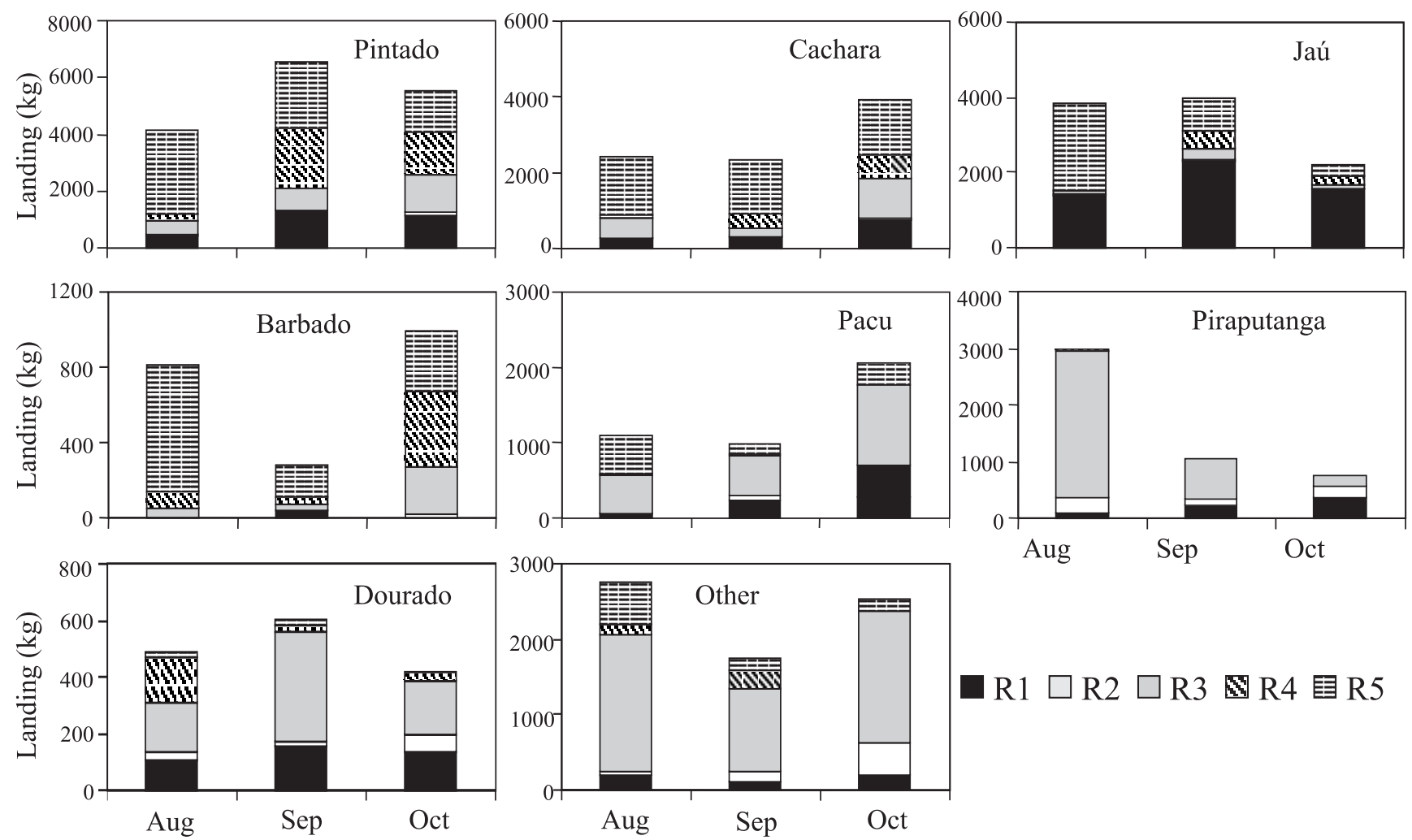

Aug

R1 $\square$ R2 $\square$ R3 R4 R5

Fig. 5. Landing by species and region of the rio Cuiabá in 2000.

from its source to its mouth. Earlier articles report that the fish commercialized in the Cuiabá Fish Market came mainly from the stretch comprised between the Distrito da Guia, a municipality of Cuiabá, and the community of Barra do Aricá, in the municipality of Santo Antônio de Leverger (Ferraz de Lima \& Chabalin, 1984), which correspond to regions 2 and 3 established here, i.e., closer to Cuiabá city. Petrere $(1983 ;$ 1985a; 1986) recorded a similar fact for the catches around Manaus, state of Amazonas (AM). Since the deterioration of the river in the proximity of urban zones is quite marked, especially as a result of the in natura discharge of domestic sewage, silting, and removal of riverine vegetation (FEMA, 1997, Priante et al., 2002), we suspected that the production have had been reduced in these regions. As Welcomme \& Bartley (1998) found, the decline in the aquatic environmental quality has led to an increasing inability of fish stock to adapt and maintain their structure and productivity.

The fish landing statistics available for the analyses here are punctual, i.e., they do not cover the entire extent of the upper rio Paraguay basin, and moreover cover only one and a half year period. It is therefore difficult to make a conclusive statement about the causes of the inter-annual variation in the catch that could be associated with environmental variation and/or fishing dynamic. In floodplain of large rivers, fluctuation in catch may occur under the same fishing regime reflecting the annual variation in the fish abundance associated with the hydrological cycle (Petrere, 1989a; Fischer et al., 1992; Welcomme, 1995; Petrere et al., 2002), as suggested for upper rio Paraguay basin (Silva, 1986; Ferraz de Lima,
1987; Catella, 2001), lower rio Paraná (Quiróz, 1990) and Amazon river basin (Ribeiro \& Petrere, 1990; Batista, 1998; Barthem, 1999). On the other hand, the inter-annual variation in catch reported here also could be associated with the fishing successes.

Fishing in Pantanal concentrates on only a few, mainly migratory species that are commercially more valuable and are associated with the regions of greatest flooding (Ferraz de Lima, 1986/87; Silva, 1986; Catella, 2001; Medeiros et al., 2002). The same holds true for most of the Paraguay-Paraná system (Baigún \& Oldani, 1998; Del Barco, 2000; Petrere et al., 2002). However, depending on the region, there is a variation in the most abundantly caught migratory group between siluriforms (Pimelodidae) or characiforms. Hilborn \& Walters (1992) considered that the choice of a given species for fishing is linked mainly to cultural and market factors, although obviously the species abundance is a considerably important factor as well. In the case of the rio Cuiabá basin, siluriforms make up the largest portion of the catch, especially Pseudoplatystoma corruscans. This group predominates also in catches of the rio São Francisco basin, where $P$. corruscans represents $86 \%$ of the catch (Godinho et al., 1997). However, it is in contrast with the catch from the río Orinoco (Venezuela) and río Magdalena (Colombia), where the catch consists predominantly of characiforms of the genus Prochilodus, which, in the rio Cuiabá basin, was economically significant in the 80 's, but today is practically absent from the landings. In the rio Orinoco basin, 

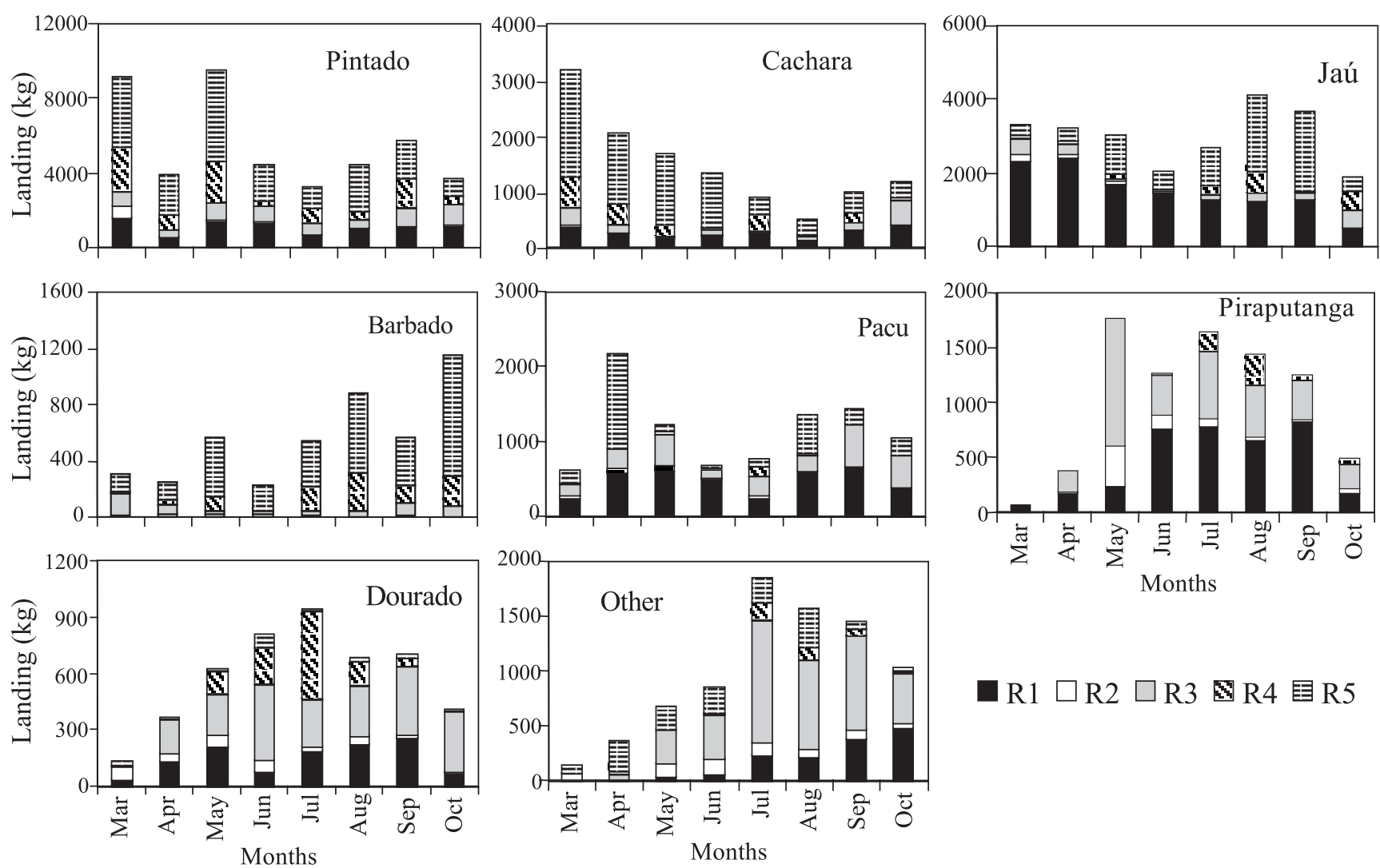

- R1 $\square \mathrm{R} 2 \square \mathrm{R} 3$ 图 4 目 $\mathrm{R} 5$

Fig. 6. Landing by species and region of the rio Cuiabá in 2001.

the contribution of Prochilodus mariae in total landings is approximately 40\% (Novoa, 1982). In the río Magdalena basin, the Prochilodus magdalenae landed from 1977 to 1988 represented about $45 \%$ of the total (Valderrama et al., 1993), reaching approximately $52 \%$ of the total catch in 1998 (Galeano et al., 2000). In these two basins, Pseudoplatystoma spp. ranks second among the commercially important fish.

In the Amazon basin, participation of Pimelodidae and Characiform in the catch varies according to the region. In the upper Amazon (Colombia), large catfish are the main component of the catch (Alonso, 1998). In the basin of the middle Amazon, characiforms make up most of the catch, mainly Colossoma macropomum and Semaprochilodus spp. (Bittencourt \& Cox-Fernandes, 1990; Batista, 1998). Pimelodids predominated in the lower Amazon basin, representing about $40 \%$ of the catch landed in Santarém (PA) in 1993, while the most important characiforms (Semaprochilodus spp.; Colossoma macropomum; Prochilodus nigricans and Leporinus spp.) together made up approximately 19\% of the total catch (Ruffino et al., 1998). In the río Pilcomayo (Bolivia), Prochilodus spp. represented more than $90 \%$ of commercial fishing from 1986 to 1989 (Estadistica e Informacion Pesquera de Bolívia, 1990).

In the rio Cuiabá, landed catch is strongly centered on a few species, mainly large pimelodids (pintado, cachara and jaú, and, in smaller quantities, barbado, jurupensém, and jurupoca) and characiforms (pacu, piraputanga, piavuçu, and dourado). In percentages, most of these species, which are sold in the Cuiabá Fish Market, originate from the rio Cuiabá basin, except for the pacu, which ranked in second place in the catch from the rio Cuiabá in the 80's (Ferraz de Lima \& Chabalin, 1984) and today ranks in fourth. More than 50\% of this species recently is caught in the rio Paraguay. One possible explanation for this may be the fact that pacu has reached its exploitation limit, both in the rio Cuiabá basin (Vaz, 2001) and in the southern part of the Pantanal (Catella, 2001; Peixer, 2003).

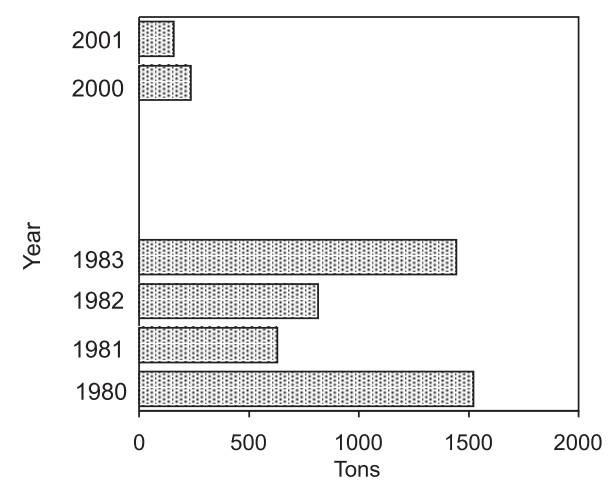

Fig. 7. Total landing of catch in the Cuiabá Fish Market from 1980 to 1983 and current data. 


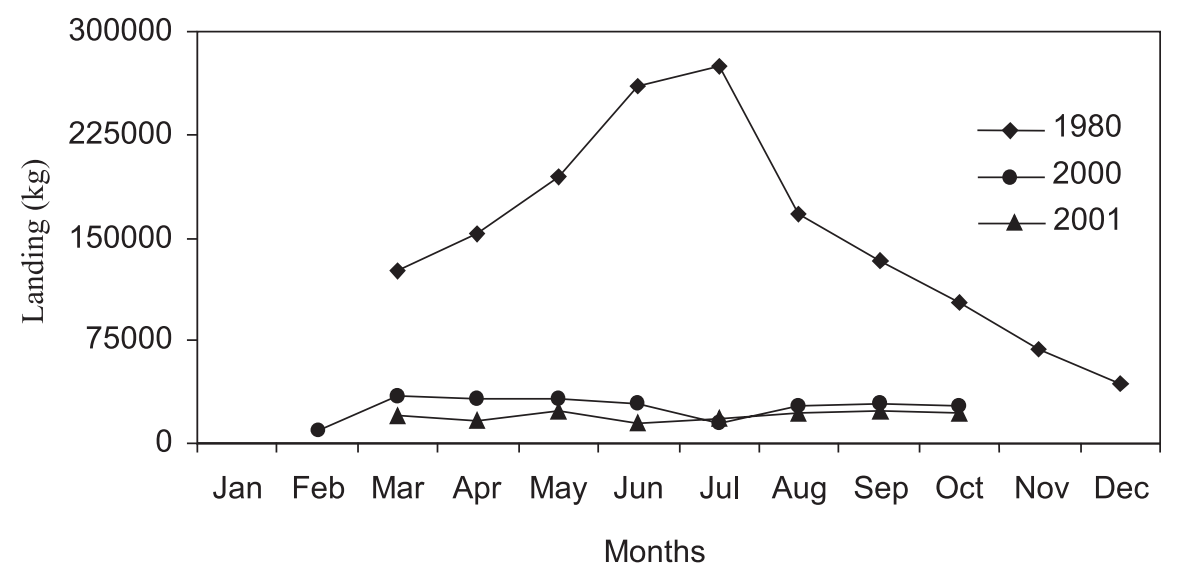

Fig. 8. Comparison of monthly landed catch in 1980 and the current data for the rio Cuiabá basin.

Although these species are distributed along the entire rio Cuiabá, there seems to be a larger concentration of jaú in the upper portion of the river, of characiforms in its middle portion, and surubim (pintado and cachara) in the lower (floodable area). However, these data are not conclusive, since this distribution may be associated with the individual preferences and skills of fishermen. Moreover, the large increase in the number of fishing sites located in regions 2 and 3 allows for part of the fish caught there to be commercialized directly to consumers. Another difficulty involved in the interpretation of this pattern is the existence of alternative landing points in almost all the regions. Those fish, which are not accounted for there, may modify the spatial pattern of catches described here.

Another factor extracted from the data is that the catches are marked seasonal for some characiforms, particularly of piraputanga and piavuçu, which appear in large numbers from May to September and July to September, respectively, and are practically impossible to find during other times of the year. The main question here is: where are these fish in the months when they are not caught? A possible explanation is their dispersion into the floodplain, since the period when they are most abundantly caught coincides with the period in which the individuals remain in the river beds, beginning to form shoals for their reproductive migration. Furthermore, because this is the period of low waters, food may be scarce, facilitating the fish attraction for bait. The large catfish, in contrast, appear to be always available for fishing, despite the variation in catches and a probable tendency to decrease during the dry season, when large carnivores do not feed voraciously (Welcomme, 1979), which may reduce successful hook and line fishing.

As mentioned earlier herein, the state of Mato Grosso do Sul today has a Fishing Control System - SCPESCA. Catella (2001) summarizes the data collected so far and analyzes the current situation of fishing, encompassing professional and sports fishing. In comparison with the data presented here, professional fishing in MS catches similar quantities of pacu and pintado (Catella, 2001) while, in MT, the largest catches are of pintado. This tendency is revealed in analyses of both monthly landings and annual total. Another difference involves the catch of piraputanga, which is negligible in MS, but which is considerably important in the total catch landed in MT. The occurrence in the catches of the other species is approximately equivalent in the north and south Pantanal.

In addition to the ecological issues relating to stock abundance and distribution, a subject yet little studied in the Pantanal, these regional differences may be attributed to individual preferences of fishermen and local markets. However, the lack of in-depth studies regarding both the socioeconomic of fishing and the ecology of target species preclude a more consistent analysis about these regional differences.

The production from commercial fishing in the rio Cuiabá, landed in the city market in 2001, was greater than the average production of commercial fishing from the other rivers in the Pantanal - the Paraguay (MS), Miranda, Aquidauana, Taquari and Apa - for the period covering the years of 1994 to 1999 (see Catella, 2001). Commercial fishing estimated for the entire rio Cuiabá basin (1,440 tons) exceeds the total production - commercial and sports fishing - in the other rivers (see Catella, 2001). This reflects, among other factors, the greater number of commercial fisheries in the entire rio Cuiabá basin (Catella, 2001; Mateus, 2003).

All no regulated or poorly regulated fishing tends to collapse. Signs that a given fishing system has adversely affected fish stocks can be identified by reductions in the total amount of the catch and by the number and ranking of species landed (Welcomme, 1999). The latter factor may lead to fishing down food web, which is characterized as a process of decrease in the average trophic level of species caught (Pauly et al., 1998).

Because the recent data on the evaluation of stocks indicate that, with the exception of pacu (Vaz, 2001), some of the main species do not show signs of overfishing (Mateus, 2003; Mateus \& Estupiñán, 2002; Mateus \& Petrere, 2004; Penha, 2003), the drop in the catch from the rio Cuiabá appears to be 


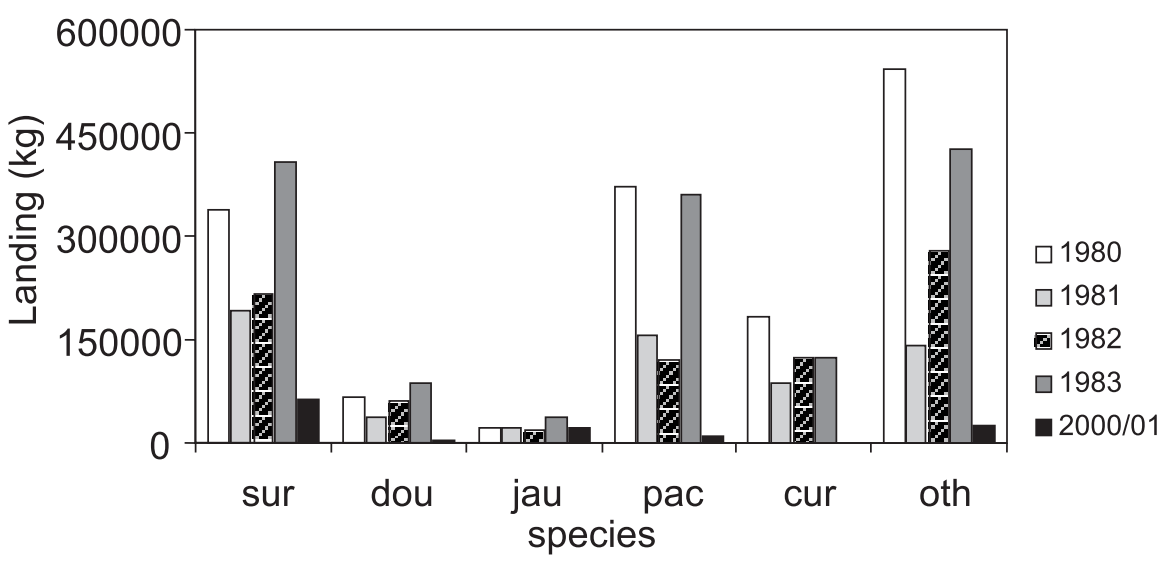

Fig. 9. Comparison of landing by species in the early 80 s and today for the rio Cuiabá basin ( $\operatorname{sur}=$ surubim; dou = dourado; jaú = jaú; pac $=$ pacu; cur = curimbatá; oth = other species $)$.

the consequence of three main factors. First, in the last few years, the government's policy has been one of establishing quite restrictive measures on fishing, such as the prohibition of gears and the establishment of total allowable catch (TAC), among others. This has limited the action of fishermen, reducing the total catch (Medeiros, 1999). Second, development of urban region in recent decades (IBGE data indicate that the population of Cuiabá almost doubled between 1980 and 2000) has caused increased deterioration of the environmental conditions of the river, possibly causing fish stocks to move away from the proximities of Cuiabá. Thus, fishing has been viable only at points far from the urban zone, leading to probable increase in the cost-benefit ratio of fishing and exclusion of many people from fishing activities, thereby contributing to the reduction in the catch. The third factor is that TAC did not exist in the early 80's, and the use of fishing nets and similar devices, though forbidden, was relatively frequent. Therefore, in addition to the larger total catch, some species rarely caught nowadays used to be caught abundantly during that period (e.g. curimbatá).

The June and July peak of the 1980's is attributed to the large catches of curimbatá (Prochilodus lineatus) during its reproductive migration. In those days, this fish was in great demand because there were cold storage plants in the region, which exported this species to other states (Ferraz de Lima \& Chabalin, 1984). The amount of curimbatá catch today is negligible, since, as mentioned earlier, the use of fishing nets is forbidden. In addition, there has been a substantial drop in its demand, since the cold storage plants in the region are no longer operational. Prochilodus lineatus is of high commercial value in other parts of the Plata basin (Verón, 1992; Bonetto, 1998), and is the most abundantly caught species in the province of Santa Fe, Argentina, in the middle portion of the rio Paraná. Part of this catch is consumed in Argentina and another is exported, mainly to Brazil (Del Barco, 2000).

Although the number and composition of species actually caught were similar to that of the 80 's, the distribution of abundances in the landing data (species ranking) changed. Fishing today catches more carnivorous species than fish from other inferior trophic levels. Thus, one sees an inverse phenomenon to that discussed by Pauly et al. (1998), i.e., there has been a "fishing-up" in the Cuiabá fish catch.

The decrease in total caught, changes in species ranking, and the "fishing-up" found in this study cannot be credit only to overfishing (Catella, 2001; Vaz, 2001; Mateus \& Estupiñán, 2002; Mateus, 2003; Peixer, 2003; Penha, 2003; Mateus \& Petrere, 2004). They seem to result from a complex interaction among overfishing, environmental degradation, changes in market preferences, and restrictive legal fishing regulations. Therefore, any attempt at bringing order to local fishing would be useless if these issues were not also taken into account.

\section{Acknowledgements}

The authors thank the Mato Grosso Forestry Police for making its landing data available. Thanks are also due to UFMT and UNESP (Brazil) for their financial support of this work, to Prof. Dr. Ângelo Agostinho for his valuable personal input, and to anonymous referees for their helpful comments.

\section{Literature Cited}

Aguirre, A. 1945. A caça e a pesca no Pantanal de Matogrosso. Brasília, Ministério da Agricultura, Departamento de Produção Animal, 47p.

Alonso, J. C. 1998. Pesca e esforço de pesca dos grandes bagres (Siluriformes: Pimelodidae) num setor colombiano do Alto Amazonas. 1998. Unpublished M.Sc. Thesis, Instituto Nacional de Pesquisas da Amazônia, Manaus. 78p.

Baigún, C. \& N. Oldani. 1998. The Hidrovia Project: should we be concerned for fish resources? In: Hayes, D. F. (Eds.) Engineering Approaches to Ecosystem Restoration. Reston, ASCE. CD-Rom. 
Barthem, R. B. 1999. A pesca comercial no médio Solimões e sua interação com a Reserva de Desenvolvimento Sustentável Mamirauá. Pp. 72-107. In: Queiroz, H. \& W. G. Crampton (Eds.). Estratégias para manejo de recursos pesqueiros em Mamirauá. Brasília, Sociedade Civil Mamirauá, CNPq, 208p.

Barthem, R., M. Petrere, V. Isaac, M. C. L. Ribeiro, D. G. McGranth, I. J. A. Vieira \& M. Barco. 1997. A pesca na Amazônia: problemas e perspectivas para seu manejo. Pp. 173-185. In: Manejo de Vida Silvestre para a Conservação na América Latina - Workshop e Seminário. Belém, MCTCNPq, Sociedade Civil Mamirauá. 254 p.

Batista, V. S. 1998. Distribuição, dinâmica da frota e dos recursos pesqueiros da Amazônia Central. Unpublished Ph. D. Dissertation, Instituto Nacional de Pesquisas da Amazônia, Manaus. 291p.

Bittencourt, M. M. \& C. Cox-Fernandes. 1990. Peixes migradores sustentam a pesca comercial. Ciência Hoje, 11(4):20-24.

Bonetto, A. 1998. Panorama sinóptico sobre la ictiofauna, la pesca y piscicultura en los ríos de la cuenca del Plata, con especial referencia al Paraná. Revista de Ictiología, 6:3-16.

Carvalho, N. O. 1986. Hidrologia da bacia do Alto Paraguai. Pp. 43-49. In: I Simpósio Sobre Recursos Naturais e Sócio-Econômicos do Pantanal, 1. Anais. Brasília: EMBRAPA-DDT. 265p.

Catella, A. C. 2001. A pesca no Pantanal de Mato Grosso do Sul, Brasil: descrição, nível de exploração e manejo (19941999). Unpublished Ph. D. Dissertation, Instituto Nacional de Pesquisas da Amazônia, Manaus. 351p.

Del Barco, D. M. 2000. Informe sobre la situación actual de la actividad pesquera en la provincia de Santa Fe. Seminario Internacional de Pesca Continental. Santa Fé, Argentina, 6 e 7 dezembro de 2000. 13p.

Estadística e Información Pesquera de Bolivia (1980-1989). 1990. Relatoría. Ministerio de Asuntos Campesinos Y Agropecuarios. La Paz, Bolivia. 43p.

FEMA - Fundação Estadual do Meio Ambiente. 1995. Caracterização Hidrográfica do Estado de Mato Grosso. Relatório Preliminar. Cuiabá, 537p.

FEMA - Fundação Estadual do Meio Ambiente. 1997. Qualidade da água dos principais rios da bacia do Alto Paraguai: 1995-1996. MMA-PNMA, Cuiabá, 118p.

Ferraz de Lima, J. A. 1981a. A pesca no Pantanal de Mato Grosso (rio Cuiabá: biologia e ecologia pesqueira). In: II Congresso Brasileiro de Engenharia de Pesca, Recife. Anais. p. 503-515.

Ferraz de Lima, J. A. 1981b. A pesca no Pantanal de Mato Grosso (rio Cuiabá: Aspectos da produção pesqueira). II Congresso Brasileiro de Engenharia de Pesca, Recife. Anais. p. 517-529.

Ferraz de Lima, J. A. 1986/87. A pesca no pantanal de Mato Grosso (Rio Cuiabá: a importância dos peixes migradores). Acta Amazonica, 16/17:87-94.

Ferraz de Lima, J. A. 1987. A tecnologia de pesca no CentroOeste do Brasil (Bacia do Alto Paraguai: Pantanal de Mato
Grosso). V Congresso Brasileiro de Engenharia de Pesca, Fortaleza. Anais. p. 305-323.

Ferraz de Lima, J. A. 1993. Recursos pesqueiros em ambientes inundáveis (Rio Cuiabá: Pantanal de Mato Grosso). Encontro Brasileiro de Ictiologia. Universidade de São Paulo. Anais. p. 302-310.

Ferraz de Lima, J. A. \& E. Chabalin. 1984. O Mercado dos Peixes. Cuiabá. Prefeitura Municipal de Cuiabá. 96p.

Fischer, C. F. A., A. L. G. Amador \& L. D. C. Dornelles. 1992. Pesca de águas interiores. Brasília: Instituto Brasileiro do Meio Ambiente e dos Recursos Naturais Renováveis. Coleção Meio Ambiente. Série Estudos: Pesca, n. 2, 29p.

Galeano, I. C. B., M. Estrada \& M. Barco. 2000. Plan de Ordenación: manejo y aprovechamiento sostenible pesquero y acuícola en la cuenca del Río Grande de la Magdalena. Bogotá, INPA, 31p.

Gayanilo Jr. F. C. \& D. Pauly. 1997. The FAO-ICLARM Stock Assessment Tools (FISAT) Reference manual. FAO Computerized Information Series (Fisheries) 8, 262p.

Godinho, H. P., M. O. T. Miranda, O. L. Godinho \& J. E. Santos. 1997. Pesca e biologia do surubim Pseudoplatystoma corruscans no rio São Francisco. Pp. 27-42. In: Miranda, O. T. (org). Surubim. IBAMA, Coleção Meio Ambiente, Série Estudos: Pesca, 19, 156p.

Hilborn, R. \& C. J. Walters. 1992. Quantitative fisheries stock assessment: choice, dynamics and uncertainty. New York. Chapman and Hall. 570 p.

Mateus, L. A. F. 2003. Ecologia da pesca de quatro grandes bagres (Siluriformes: Pimelodidae) na bacia do rio Cuiabá, Pantanal Mato-grossense. Unpublished Ph. D. Dissertation, Universidade Estadual de São Paulo, Rio Claro, SP. 177 p.

Mateus, L. A. F. \& G. M. B. Estupiñán. 2002. Fish stock assessment of piraputanga Brycon microlepis in the Cuiabá River basin, Pantanal of Mato Grosso, Brazil. Brazilian Journal of Biology, 62(1):165-170.

Mateus, L. A. F. \& M. Petrere Jr. 2004. Age, growth and yield per recruit analysis of the pintado, Pseudoplatystoma corruscans Agassiz, in the Cuiabá River basin, Pantanal of Mato Grosso, Brazil. Brazilian Journal of Biology, 64(2):257-264.

Medeiros, H. Q. 1999. Impactos das políticas públicas sobre os pescadores profissionais do Pantanal de Cáceres, Mato Grosso. Unpublished M.Sc. Thesis, Universidade de São Paulo, São Paulo. 217p.

Medeiros, H. Q., V. L. Amaral, L. A. F. Mateus, J. M. F. Penha \& C. J. da Silva. 2002. Caracterização da atividade pesqueira profissional no município de Barra do Bugres, Mato Grosso. In: III Simpósio Sobre Recursos Naturais e SócioEconômicos do Pantanal, 2000, Corumbá. Anais. Brasília: Departamento de Difusão de Tecnologia. CD-Rom.

Novoa, D. R. 1982. Los Recursos pesqueros del río Orinoco y su explotación. Corporación Venezolana de Guayana, Caracas, Venezuela. 386p.

Paiva, M. P. 1983. Peixes e pescas de águas interiores do Brasil. Editerra, Brasília. 158p. 
Pauly, D., V. Christensen, J. Dalsgaard, R. Froese \& F. Torres Jr. 1998. Fishing down marine food webs. Science, 279:860-863.

PCBAP. 1995. Plano de Conservação da Bacia do Alto Paraguai. Projeto Pantanal. Programa Nacional do Meio Ambiente (PNMA). Brasília: Ministério do Meio Ambiente, Recursos Hídricos e Amazônia Legal, Brasil, $3^{\circ}$ vol. $394 \mathrm{p}$.

Peixer, J. 2003. Seletividade de anzol e rendimento por recruta do pacu Piaractus mesopotamicus (Holmberg, 1887) no Pantanal de Mato Grosso do Sul, Brasil. Unpublished M.Sc. Dissertation. Universidade Estadual de São Paulo, Rio Claro. 77p.

Penha, J. M. F. 2003. Estrutura e estado de explotação dos estoques dos bagres Hemisorubim platyrhynchos e Sorubim lima na bacia do rio Cuiabá, Pantanal Matogrossense. Unpublished Ph. D. Dissertation. Universidade Federal de São Carlos, São Carlos. 117p.

Petrere, M. Jr. 1983. Relationships among catches, fishing effort and river morphology for eight rivers in Amazonas States (Brazil), during 1976-1978. Amazoniana 8(2):281-296.

Petrere, M. Jr. 1985. A pesca comercial no Rio Solimões-Amazonas e seus afluentes: análise dos informes do pescado desembarcado no Mercado Municipal de Manaus (19761978). Ciência e Cultura, 37(12):1987-1999.

Petrere, M. Jr. 1986. Amazon fisheries II - Variation in the relative abundance of tucunaré (Cichla ocellaris, $C$. temensis) based on catch and effort data of the trident fisheries. Amazoniana, 10(1):1-13.

Petrere, M. Jr. 1989. River fisheries in Brazil: a review. Regulated Rivers: Research and Management, 4:1-6.

Petrere, M. Jr. 1992. Pesca na Amazônia. Seminário Internacional Sobre o Meio Ambiente, Pobreza e Desenvolvimento da Amazônia. Belém. Anais. p.72-78.

Petrere, M. Jr, A. A. Agostinho, E. K. Okada \& H. F. Julio Jr. 2002. Review of the fisheries in the Brazilian portion of the Paraná/Pantanal basin. Pp. 123-143. In: I. G. Cowx. (ed). Management and ecology of lake and reservoir fisheries. Oxford, Fishing News Books. 384p.

Priante, G. R., L. F. M. Apoitia, L. Maraschin, G. M. U. de Arruda, O. C. Nascimento, E. R. A. Matos, L. S. Couto, C. M. London, L. S. Lotufo, S. H. C. Campos, L. H. M. Noquelli, N. C. Pinheiro \& C. R. de Musis. 2002. Qualidade de Água da Bacia do Rio Cuiabá, da Nascente até Exutório Porto Cercado, Pantanal Poconé, Mato Grosso. In: III Simpósio Sobre Recursos Naturais e Sócio-Econômicos do Pantanal, 2000, Corumbá. Anais. Brasília: Departamento de Difusão de Tecnologia. CD-Rom.
Quiróz, R. 1990. The Paraná river basin development and the changes in the lower basin fisheries. Interciencia, 15:442451.

Ribeiro, M. C. L. B. \& M. Petrere Jr. 1990. Fisheries ecology and management of the jaraqui (Semaprochilodus taeniurus, S. insignis) in Central Amazonian. Regulated Rivers: Research \& Management, 5:195-205.

Ruffino, M., V. J. Isaac \& A. Milstein. 1998. Fisheries ecology in the Lower Amazon: a typical artisanal practice in the tropics. Ecotropica, 4:99-114.

da Silva, C. J. 1990. Influência da variação do nível da água sobre a estrutura e funcionamento de uma área alagável do Pantanal Matogrossense (Pantanal de Barão de Melgaço, Município de Santo Antônio de Leveger e Barão de Melgaço-MT). Unpublished Ph.D. Dissertation, Universidade Federal de São Carlos, São Carlos. 250p.

da Silva, C. J. \& J. A. F. Silva. 1995. No ritmo das águas do Pantanal. São Paulo, NUPAUB/USP. 194p.

Silva, M. V. 1986. Mitos e verdades sobre a pesca no Pantanal sul mato-grossense. Campo Grande, FIPLAN / MS. 146p.

Valderrama, M., M. Petrere Jr., M. Zarate \& G. V. Uribe. 1993. Parámetros poblacionales (mortalidad, rendimiento Máximo sostenible y estado de explotación del bocachico Prochilodus magdalenae (Steindachner, 1878; Prochilodontidae) del Bajo rio Magdalena (Colombia). Bulletin Cientifico INPA, 1:43-60.

Vaz, M. M. 2001. Problemas no ajuste da curva de crescimento do pacu, Piaractus mesopotamicus (Holmberg, 1887) (Pisces: Characidae), e seu manejo no Pantanal Matogrossense Unpublished Ph.D. Dissertation. Universidade Estadual de São Paulo, Jaboticabal. 98p.

Verón, M. B. C. 1992. La pesca comercial en el río Paraná (Chaco, Argentina). Ambiente Subtropical, 2:125-149.

Welcomme, R. 1979. Fisheries ecology of floodplain rivers. London Logman, 317p.

Welcomme, R. 1995. Relationship between fisheries and the integrity of river systems. Regulated Rivers: Research \& Management, 11:121-136.

Welcomme, R. 1999. A review of a model for qualitative evaluation of exploitation levels in multi-species fisheries. Fisheries Management and Ecology, 6:1-19.

Welcomme, R. \& D. M. Bartley. 1998. Current approaches to the enhancement of fisheries. Fisheries Management and Ecology, 5:351-382.

Received March 2004 Accepted October 2004 